\title{
Loricifera from the deep sea at the Galápagos Spreading Center, with a description of Spinoloricus turbatio gen. et sp. nov. (Nanaloricidae)
}

\author{
Iben Heiner • Birger Neuhaus
}

Received: 1 August 2006 / Revised: 26 January 2007 / Accepted: 29 January 2007 / Published online: 10 March 2007

(C) Springer-Verlag and AWI 2007

\begin{abstract}
Specimens of a new species of Loricifera, Spinoloricus turbatio gen. et sp. nov., have been collected at the Galápagos Spreading Center (GSC) during the cruise SO 158, which is a part of the MEGAPRINT project. The new genus is positioned in the family Nanaloricidae together with the three already described genera Nanaloricus, Armorloricus and Phoeniciloricus. The postlarvae and adults of Spinoloricus turbatio gen. et sp. nov. are characterized by a mouth cone with eight oral ridges and basally with a cuticular reinforcement named mouth cone pleat; eighth row with 30 whip-like spinoscalids and 30 "alternating" plates; thorax with eight single and seven double trichoscalids, where the single trichoscalids are twice the length of the double ones, and the secondary appendage on the double trichoscalid is smooth whereas the others are serrated; lorica with eight cuticular plates with additional spikes in the anterior corners and intercalary plicae between the plates. Some of these genus-specific characters such as the mouth cone pleat, the "alternating" plates and the intercalary plicae have not been observed in Nanaloricidae before. The Higgins-larvae of Spinoloricus turbatio gen. et sp.
\end{abstract}

Communicated by H.-D. Franke.

\footnotetext{
I. Heiner $(\bowtie)$

Zoological Museum,

The Natural History Museum of Denmark,

University of Copenhagen,

Universitetsparken 15,

2100 Copenhagen, Denmark

e-mail: iheiner@snm.ku.dk

B. Neuhaus

Museum für Naturkunde der Humboldt-Universität zu

Berlin, Invalidenstr. 43, 10115 Berlin, Germany
}

nov. are characterized by six rectangular plates in the seventh row with two teeth, an indistinct honeycomb sculpture and long toes with little mucrones. The SO 158 cruise has yielded a minimum of ten new species of Loricifera out of only 42 specimens. These new species belong to two different orders, where one being new to science, and three different families. This result indicates a high diversity of loriciferans at the GSC. Nearly all the collected loriciferans are in a moulting stage, hence there is a new stage inside the present stage. This prolongation of life stages and the occurrence of multiple life stages inside each other are typical of deep-sea loriciferans. Here exemplified by the two postlarvae with adults inside, which is observed for the first time in Nanaloricidae.

Keywords Loricifera $\cdot$ Nanaloricidae $\cdot$ Spinoloricus turbatio gen. et sp. nov. · Galápagos $\cdot$ SO 158

\section{Introduction}

The coastal interstitial fauna of the Galápagos Islands has been extensively studied by Prof. Peter Ax and a large team of co-workers and was published in about 40 articles mainly in the series Mikrofauna des Meeresbodens and the successor Microfauna Marina starting with the introductory article by $\mathrm{Ax}$ and Schmidt (1973). Westheide (1991) summarized this mostly German information in an English review, which included more than 390 species of the Galápagos meiofauna and several new records. Otherwise, the meiofauna of the Central American East Pacific is poorly known. Mielke (1995) described six species of Copepoda from the coast of Costa Rica and provided evidence for the 
repeated colonization of the Galápagos Islands and possible speciation events in this taxon (Mielke 2003). Guzmán et al. (1987) investigated coral reef meiofauna; Cruz and Vargas (1987) and Vargas (1988) reported meiofauna from mudflats at the Golf of Nicoya in Costa Rica. All these studies mention meiofauna at group level. The kinorhynchs mentioned in Cruz and Vargas (1987) and Vargas (1988) from the Pacific coast of Costa Rica were assigned to Echinoderes and Kinorhynchus by the junior author (own unpublished results). Recently, a new genus of Kinorhyncha, Fissuroderes has been collected and described from the continental shelf of Costa Rica and New Zealand (Neuhaus and Blasche 2006).

Concerning the deep-sea meiofauna in the Central American East Pacific area only one kinorhynch species has been identified to species level, Campyloderes cf. vanhoeffeni Zelinka, 1913 (Neuhaus 2004). The only other description of a deep-sea kinorhynch from the American East Pacific Deep Sea is Antygomonas oreas Bauer-Nebelsick 1996 from a seamount at 500-700 m depth (Bauer-Nebelsick 1996). However, this record is from the northern, and not the central, part of the American East Pacific. Unpublished observations by the junior author based on material from the two German deep-sea expeditions SO 144-3 and SO 158 with $\mathrm{R} / \mathrm{V}$ Sonne in the Central American East Pacific suggest a high diversity of Kinorhyncha and other meiofauna, such as Tardigrada and Gastrotricha in the deep sea, nearly all species being new to science.

The phylum Loricifera consists of exclusively bilateral microscopic marine metazoans living either in the interstices of different types of sand or in mud. The phylum including the type species Nanaloricus mysticus Kristensen, 1983 was described in 1983 from shell gravel (Dentalium sand) off the coast of Roscoff, France (Kristensen 1983). The type species belongs to the family Nanaloricidae, which presently comprises three genera Nanaloricus, Phoeniciloricus and Armorloricus (see Kristensen 1983; Gad 2004; Kristensen and Gad 2004). In the genus Nanaloricus only two species N. mysticus and Nanaloricus khaitatus Todaro and Kristensen, 1998 have been described (Kristensen 1983; Todaro and Kristensen 1998), however, several species are currently under description, e.g., a new species from Fort Pierce, USA (Kristensen et al. 2007) and two new species from Roscoff, France (unpublished results by senior author). The genus Armorloricus, including the two species Armorloricus elegans Kristensen and Gad, 2004 and Armorloricus davidi Kristensen and Gad 2004 was described from Roscoff, France and shortly thereafter another species of this genus, Armorloricus kristenseni Heiner, 2004 was described from the Faroe Bank, North Atlantic (Heiner 2004). It was assumed for long that species of Nanaloricidae prefer shallow sandy waters (Gad 2004). However, this was recently disproved when a new genus and species, Phoeniciloricus simplidigitatus Gad, 2004 belonging to Nanaloricidae was described from the deep sea near the Kilinailau Trench close to Papua New Guinea (Gad 2004). Presently, only three other Loricifera species are known from the deep sea; Pliciloricus hadalis Kristensen and Shirayama, 1988 from the Izu-Ogasawara Trench, Western Pacific (Kristensen and Shirayama 1988), and Titaniloricus inexpectatovus Gad, 2005 as well as Pliciloricus pedicularis Gad, 2005, both from the Angola Basin, Southeast Atlantic (Gad 2005a, b). Very little is known about the life cycles of deep-sea loriciferans, since most of the species are known from only a few specimens and complete series of instars are lacking. Hence, investigations of these animals are highly desirable.

During the geological deep-sea expedition SO 158 (MEGAPRINT $=$ Multidisciplinary Examination of Galápagos Plume Ridge Interaction), Dr Peter Götz and the junior author had the opportunity to collect all biological material brought on board of R/V Sonne by petrological sampling and from five biological stations (Werner 2002). This paper is the third in a series about the biological results of SO 144-3 and SO 158 to the Galápagos area.

\section{Materials and methods}

All specimens were collected with $\mathrm{R} / \mathrm{V}$ Sonne during cruise SO 158 on and near the Galápagos Spreading Center (GSC) and in a transform fault zone in the Central American East Pacific (Fig. 1; Werner 2002). Biological material was obtained either by two sediment traps (tube diameter $4 \mathrm{~cm}$, tube length $21 \mathrm{~cm}$ ) in a geological chain sack dredge or by a meiofauna dredge. Meiofauna was extracted by density gravity centrifugation with Levasil (Werner 2002). Sediment was immediately fixed in $6-8 \%$ formaldehyde buffered with buffer tablets for haematology at $\mathrm{pH}=7.0$ (Merck 109468), carefully washed with plenty of tap water on a $40 \mu \mathrm{m}$ sieve about one day after fixation, mixed with Kaolin (Riedel de Haën 18616) centrifuged in a largevolume centrifuge Thermo Heraeus megafuge $3 \mathrm{~s}$ with three times the amount of Levasil $200 \mathrm{~A} / 40 \%$ (Bayer), three times at $4,000 \mathrm{rpm}$, rinsed with tap water, stored in $75 \%$ ethanol, later transferred to an ethanol-glycerine mixture for $1-2 \mathrm{~h}$, and the ethanol allowed to evaporate overnight. Individuals were placed in a tiny drop of pure glycerine on a cover slip, surrounded by paraffin, 
Fig. 1 Map of study area of the deep-sea expedition SO 158. Land masses in dark grey, submarine ridges marked in light grey. Numbers next to black dots refer to sample stations mentioned in the text. Map designed by courtesy of Reinhard Werner, IfM-GEOMAR Kiel

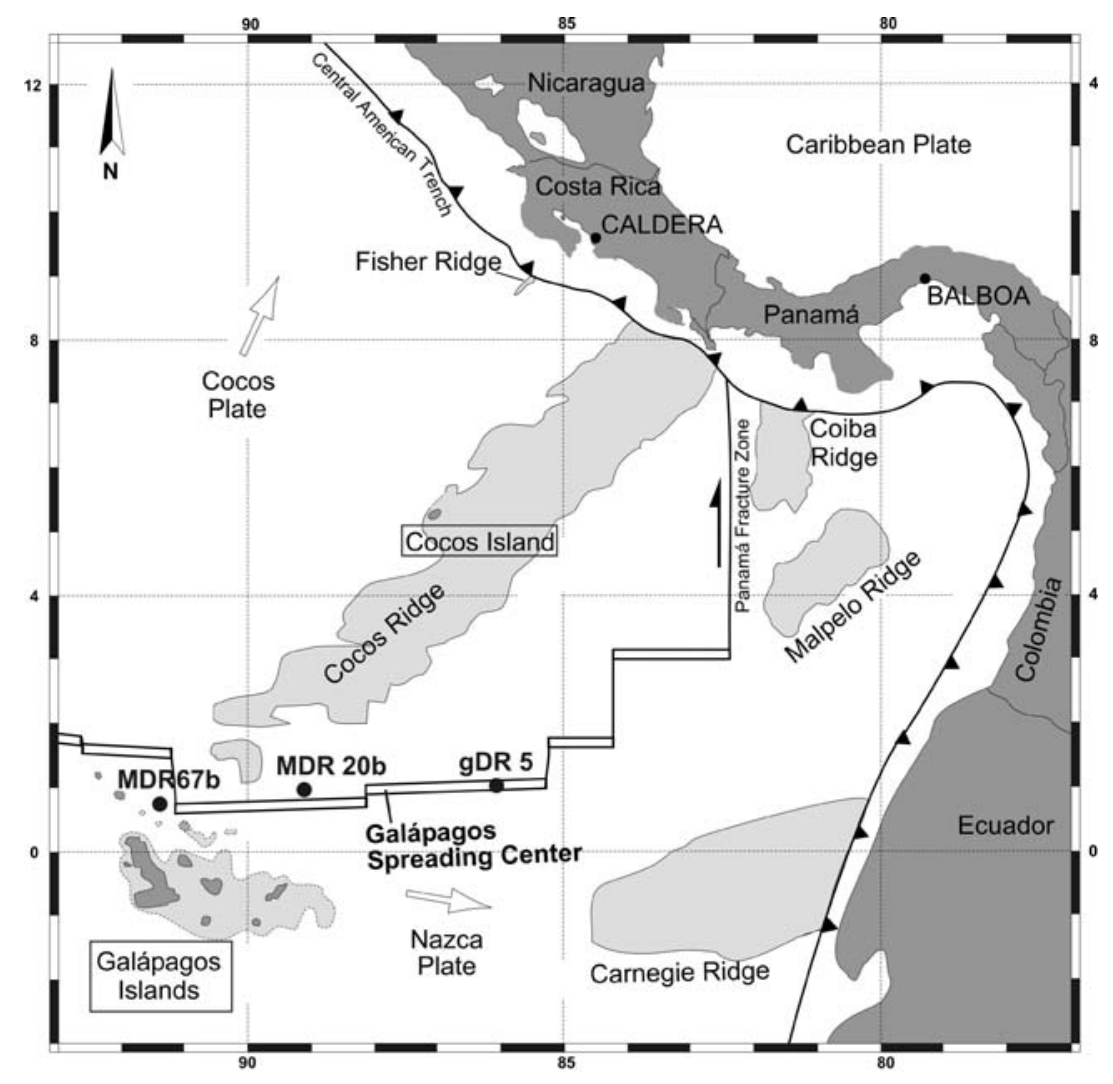

and carefully manipulated with a second coverslip after melting of the paraffine. Finally the coverslips were sealed with Glyceel prepared according to the recipe by Bates (1997) and placed in a Cobb-aluminium slide for microscopic observation from both sides. For more information concerning the density gravity centrifugation method with Levasil (see Werner 2002; Neuhaus 2004; Neuhaus and Blasche 2006).

\section{Results}

The species from near the Galápagos Spreading Center

A total of 42 specimens have been collected from ten different stations on or near the GSC during the cruise SO 158. The specimens belong to a minimum of ten new species of two different orders, Nanaloricida and a new order (Table 1). One new species, Spinoloricus tubatio gen. et sp. nov., in the family Nanaloricidae, and eight new species in the family Pliciloricidae are members of the Nanaloricida.

The family Pliciloricidae is represented by three new species of Pliciloricus, two new species of Rugiloricus and one new genus with three new species (Table 1). In Pliciloricus nov. sp. 1 only early instar Higgins-larvae
Table 1 Species list of the loriciferan fauna around Galápagos Spreading Center

Nanaloricida

Nanaloricidae

Spinoloricus turbatio gen. et sp. nov.

Pliciloricidae

Pliciloricus nov. sp. 1

Pliciloricus nov. sp. 2

Pliciloricus nov. sp. 3

Rugiloricus nov. sp. 1 (cauliculus-type)

Rugiloricus nov. sp. 2 (carolinensis-type)

nov. gen. 1 et nov. sp. 1

nov. gen. 1 et nov. sp. 2

nov. gen. 1 et nov. sp. 3

New order

New family

nov. gen. 2 et nov. sp. 1

and last instar Higgins-larvae with adults inside have been found. In Pliciloricus nov. sp. 2 only one Higginslarva with an adult inside is found and Pliciloricus nov. sp. 3 consists of a single adult surrounded by the cuticle of a postlarva.

In the genus Rugiloricus two species have been found, one species of the carolinensis-type where the adult comes directly out of the Higgins-larva since the postlarval stage is reduced, and one species of the cauliculus-type with the presence of a free-living postlarva 
(see Kristensen and Brooke 2002). Special for Rugiloricus nov. sp. 1 (cauliculus-type) is the finding of a highly reduced larva, called ghost-larva. The first time this type of reduced larva was collected was in 1986 by Jeanne Renaud-Mornant at 3,660 m depth in the Bay of Biscay (Kristensen et al. 2003). Ghost-larvae are now known from several species of Rugiloricus primarily from the Faroe Bank (Heiner 2005), but also from species of the genus Pliciloricus (Gad 2005b, c). Rugiloricus nov. sp. 1 (cauliculus-type) consists, besides the ghost-larva, of two Higgins-larvae, a Higgins-larvae with a postlarva, a postlarva with an adult inside and an adult male. Only two specimens of Rugiloricus nov. sp. 2 (carolinensis-type) have been found, both are Higgins-larvae with an adult inside.

The new genus in Pliciloricidae, nov. gen. 1, with three new species (Table 1) belongs to the same undescribed genus found several times by other expeditions such as, ANTARKTIS XIII/5 with RV Polarstern and M $42 / 3$ to the Great Meteor Seamount with R/V Sonne (Gunnar Gad, unpublished data). This genus is characterized by Higgins-larvae, which have a protruding mouth cone; a simple hexagonal bipyramidal internal armature, clavoscalids with a large round distal part, two pairs of ventral setae; long thin toes and two pairs of posterior setae. Some of the Higgins-larvae possess a pattern of pores in different places on the cuticle of the thorax and abdomen. These pores, called collar flosculi by Gad (2004), are connected to gland cells and are therefore not homologous to the typical flower-shaped flosculi found in Loricifera. An additional observation is that in this genus the introvert is never totally retracted when the Higgins-larva is moulting, which contrasts with the moulting Higginslarvae of Rugiloricus. The three new species can easily be distinguished from each other by the shape of the toes of the Higgins-larvae. The adults of this new genus are characterized by an extremely long trumpetlike mouth tube, which is widest distally. Additionally, all the trichoscalids are single, very wide, highly serrated and with a very pronounce middle ridge. The abdomen has many plicae, with no midventral plica and anteriorly ending in a large anal field. A remarkable observation is that all adults found in all three new species have been males with a large pair of testes inside.

Finally, the new genus, nov. gen. 2, belongs to a new order, which is identical to that reported from the Faroe Bank, though the species is new (Heiner 2005). This new order is characterized by a very large cyst-like ghost-larva in which a complex paedogenetic life cycle occurs with several moults involved (see Heiner 2005 for further information).

\section{Taxonomy}

Phylum Loricifera Kristensen, 1983

Order Nanaloricida Kristensen, 1983

Family Nanaloricidae Kristensen, 1983

Spinoloricus gen. nov.

\section{Etymology}

The generic name Spinoloricus comes from the Latin words spino for spine and lorica for corselet or girdle, masculine gender. The word spino refers to the additional short spikes (sometimes referred to as spines) found on the anterior corners of the lorica plates in the postlarvae and adults (see arrows Figs. 2, 5e).

\section{Genus diagnosis}

Postlarva/adult: Mouth cone with eight oral ridges of two different lengths and without sclerotized furcae; basally with a unique structure, a mouth cone pleat. Introvert with eight or nine rows of scalids (7th row is missing in the postlarva); 3rd row with seven robust feather-shaped scalids; 5th and 6th row with $30 \mathrm{seg}$ mented scalids with two stiff hairs; 8th row with 30 whip-like scalids and 30 "alternating" plates; 9th row with 30 beak-like scalids situated on round basal plates and with two stiff hairs. Thorax with eight single and seven double trichoscalids; single trichoscalids are twice the length of the double ones; double trichoscalids with one serrated and one smooth appendage. Lorica with eight cuticular plates and intercalary plicae between the plates; lorica plates with additionally spikes in the anterior corners and honeycomb sculpture; and nine flower-shaped flosculi.

Higgins-larva: Mouth cone without external and internal armature. Introvert with seven rows of scalids; 2nd row with six spinoscalids; 7th row with six rectangular plates with two small teeth, six short scalids and one clavoid smooth scalid. Thorax with three pairs of ventral setae where the anterolateral seta is very long with a pronounced knee, the other two pairs are clawshaped. Lorica with an indistinct honeycomb sculpture; two tubes connected to multicellular glands are found laterally; three pairs of posterior setae, where the posterodorsal setae are quite long; toes long with very little mucrones; three flosculi.

\section{Remarks}

In the family Nanaloricidae, the postlarva is morphological identical to the adult female with the only exceptions that the seventh row of scalids on the introvert and mature gonads are missing. The differ- 
Fig. 2 Drawing of the holotypic postlarva of Spinoloricus turbatio gen. et sp. nov., ventral view. The arrows indicate the additional spikes. $a l$

"Alternating" plates, $b u$ buccal tube, $c s$ clavoscalid, ip intercalar plica, lo lorica, $l p_{1-2}$ lateral lorica plates, $m c$ mouth cone, mo mouth opening, $m p$ mouth cone pleat, $o r_{1}$ primary oral ridge, $o r_{2}$ secondary oral ridge, $s r_{2-9}$ scalid in 2 nd to 9 th row, th thorax, $t p_{1-3}$ trichoscalid basal plates $1-3, t r_{a}$ single trichoscalid, $t r_{b 1}$ primary appendage of double trichoscalid, $t r_{b 2}$ secondary appendage of double trichoscalid, $v p$ ventral lorica plate

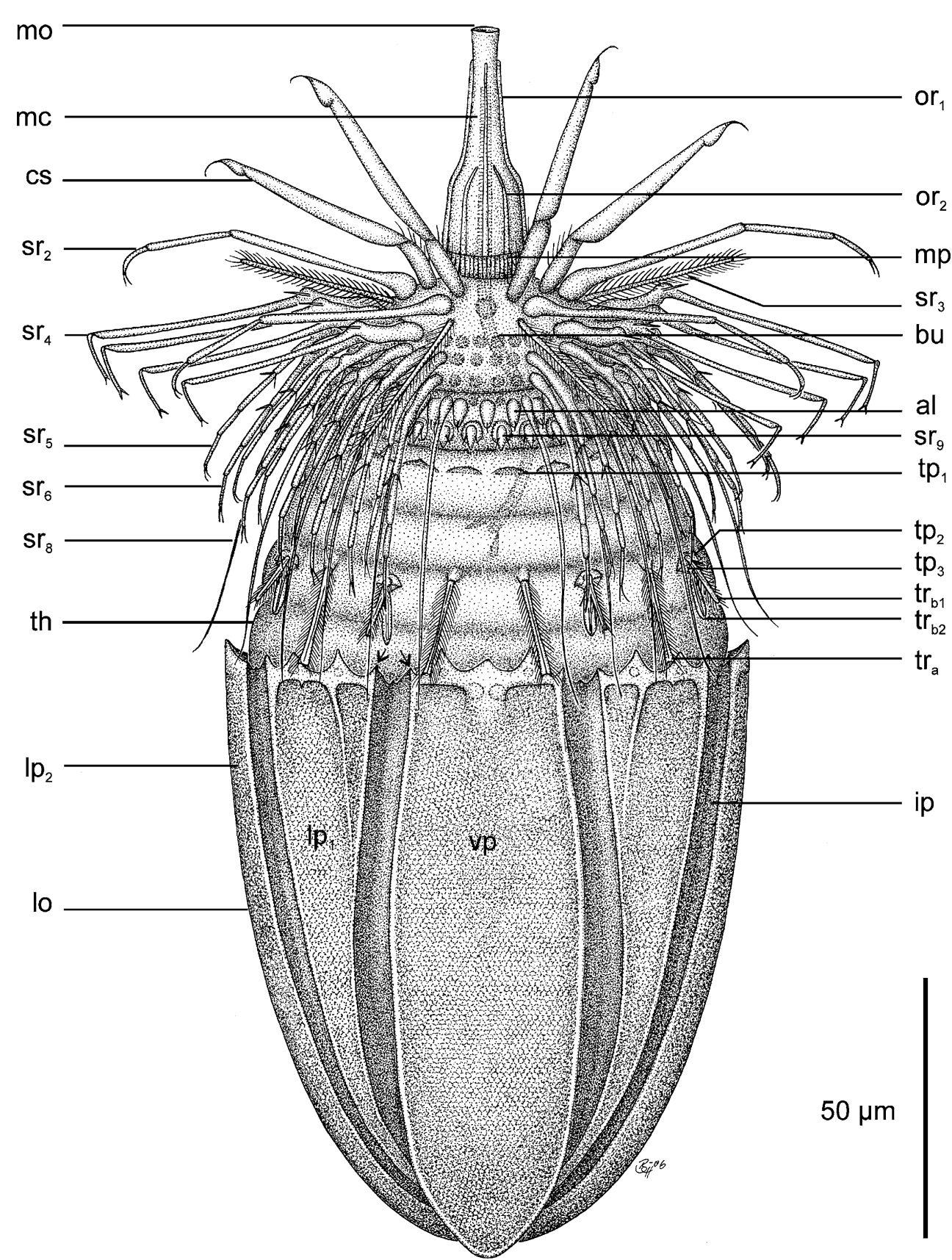

Species diagnosis

Same as the genus

\section{Material examined}

Holotype: One postlarva with an adult of unknown gender inside (SO 158, meiofauna dredge station MDR 20b, on bottom $0^{\circ} 57.277^{\prime} \mathrm{N}, 88^{\circ} 18.463^{\prime} \mathrm{W}$, off bottom $0^{\circ} 57.285^{\prime} \mathrm{N}, 88^{\circ} 18.307^{\prime} \mathrm{W}, 2,493-2,496 \mathrm{~m}$, date 31.07.2001 (Figs. 2, 3, 4, 5). Paratypes: One postlarva with an adult of unknown gender inside and one

Figs. 2-10 


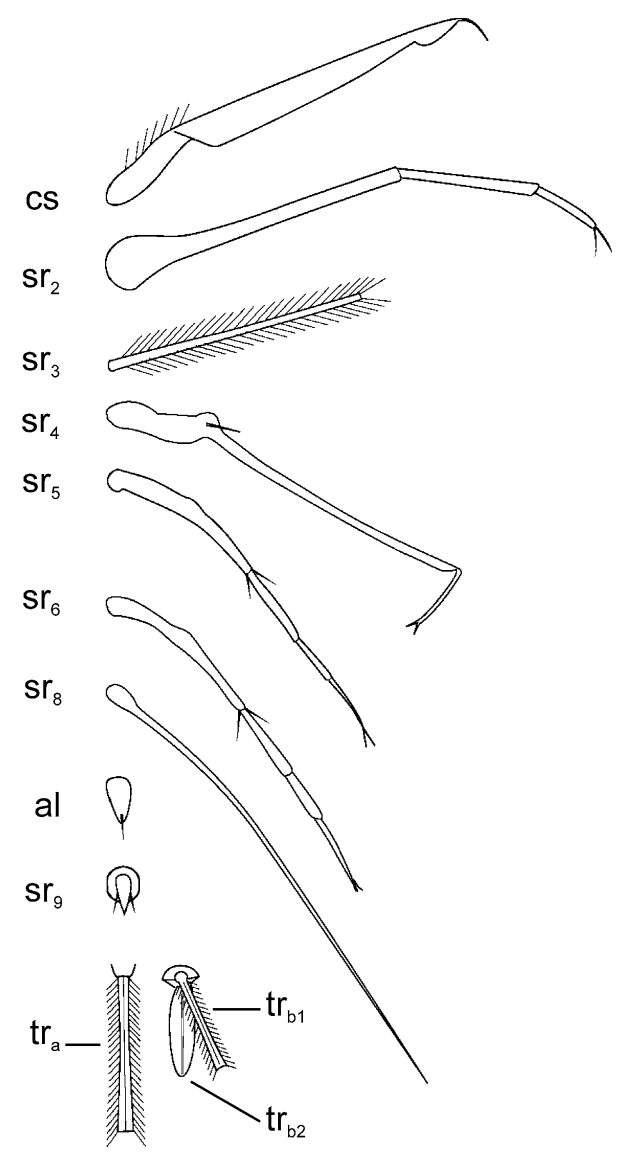

Fig. 3 Detail drawing of the different rows of scalids on the introvert of the postlarva. al "Alternating" plates, $c s$ clavoscalid, $s r_{2-9}$ scalid in 2 nd to 9th row, $t r_{a}$ single trichoscalid, $t r_{b 1}$ primary appendage of double trichoscalid, $t r_{b 2}$ secondary appendage of double trichoscalid

Higgins-larva (paratypes 1 and 2; SO 158, meiofauna dredge station MDR 67b, on bottom $0^{\circ} 51.80^{\prime} \mathrm{N}, 91^{\circ} 8.70^{\prime}$ $\mathrm{W}$, off bottom $0^{\circ} 51.80^{\prime} \mathrm{N}, 91^{\circ} 8.56^{\prime} \mathrm{W}, 2,121-2,119 \mathrm{~m}$, date 10.08.2001) as well as one Higgins-larva (paratype 3; SO 158 , dredge station DR 5, on bottom $1^{\circ} 0.996^{\prime} \mathrm{N}$, $86^{\circ} 13.99^{\prime} \mathrm{W}$, off bottom $1^{\circ} 1.767^{\prime} \mathrm{N}, 86^{\circ} 13.965^{\prime} \mathrm{W}, 2,776-$ 2,633 m, date 28.07.2001) (Figs. 6, 7, 8, 9, 10).

\section{Deposition of material}

All specimens are deposited at the Museum für Naturkunde (Humboldt University, Berlin, Germany) in the "worm" collection and catalogued in the "Generalkatalog freilebende Würmer" under the numbers ZMB Vermes 11209 (holotype), 112010a-b (paratypes from MDR 67b) and 112011 (paratype from DR 5).

\section{Etymology}

The species name turbatio is the Latin word for disturbance and confusion, which refers to the geological and tectonical movements happening in the GSC, where the two plates Cocos and Nazca are pushed away from each other causing disturbances in the ocean floor (see Fig. 1).

\section{Description of the postlarva/adult}

The holotypic postlarva (Figs. 2, 3, 4, 5) is $237 \mu \mathrm{m}$ long and has a maximum width of $100 \mu \mathrm{m}$. The paratypic postlarva is larger; $279 \mu \mathrm{m}$ long with a semi-retracted mouth tube and $119 \mu \mathrm{m}$ wide. The body is divided into a mouth cone, introvert, neck, thorax and loricated abdomen.

The mouth cone $(\mathrm{mc})$ is short $(48 \mu \mathrm{m})$ and consists of eight oral ridges of two different lengths. The primary oral ridges $\left(\right.$ or $\left._{1}=37 \mu \mathrm{m}\right)$ are twice the length of the secondary oral ridges $\left(\right.$ or $\left._{2}=17 \mu \mathrm{m}\right)($ Figs. $2,4,5 \mathrm{~b})$. Posterior to the oral ridges, at the base of the mouth cone, is a reinforcement of many longitudinal ridges named mouth cone pleat $(\mathrm{mp})$. Internally, there is a spiralized buccal tube (bu), which has been detached from the pharyngeal bulb because of the presence of an adult inside (Fig. 5d).

The introvert consists of eight or nine rows of scalids depending on whether it is a postlarva or an adult, since the seventh row is absent in the postlarvae (Fig. 3). The first row (cs) consists of eight clavoscalids $(51 \mu \mathrm{m})$ divided into four segments. The first segment possesses a large elongated basis with several stiff hairs, the second segment is long, the third is short and rounded, and the fourth and terminal segment is hook-shaped. The second row $\left(\mathrm{sr}_{2}\right)$ consists of nine larger leg-shaped spinoscalids $(71 \mu \mathrm{m})$ divided into three segments. There is no distinct basis on this scalid, so the first segment is over half the length of the whole scalid $(37 \mu \mathrm{m})$, the second is half the length of the first, and the third segment is short ending in two thin hairs. The second and the third row alternate asymmetrically, since there are nine scalids in the second row and only seven in the third. The third row $\left(\mathrm{sr}_{3}\right)$ consists of seven feather-shaped spinoscalids. The feather-shaped scalids are quite robust, short $(30 \mu \mathrm{m})$ and show numerous short thick hairs. The fourth row $\left(\mathrm{sr}_{4}\right)$ consists of 16 smaller leg-shaped scalids of only one type. The smaller leg-shaped scalids are $55 \mu \mathrm{m}$ long and divided into three segments. The first segment has an elongated basis, which terminates in a pronounce knee with two thick spines, the second segment is thin and long, and the third is short, formed like a claw and terminates into two short stiff hairs. The fifth and the sixth rows $\left(\mathrm{sr}_{5-6}\right)$ consist of 30 foursegmented spinoscalids each. The four-segmented scalids are $40 \mu \mathrm{m}$ long. The first segment is nearly half the 
Fig. 4 Drawing of the holotypic postlarva of Spinoloricus turbatio gen. et sp. nov. with an adult inside, dorsal view. $a c$ Anal cone, $a d$ adult, $b r$ brain, $b u$ buccal tube, $c s$ clavoscalid, $d p_{1-2}$ dorsal lorica plates, $f$ flower-shaped flosculus, ip intercalar plica, $l p_{2}$ dorsolateral lorica plate, $m c$ mouth cone, mo mouth opening, $m p$ mouth cone pleat, $o r_{1}$ primary oral ridge, $o r_{2}$ secondary oral ridge, $p h$ pharynx, $s r_{2-8}$ scalid in 2 nd to 8 th row

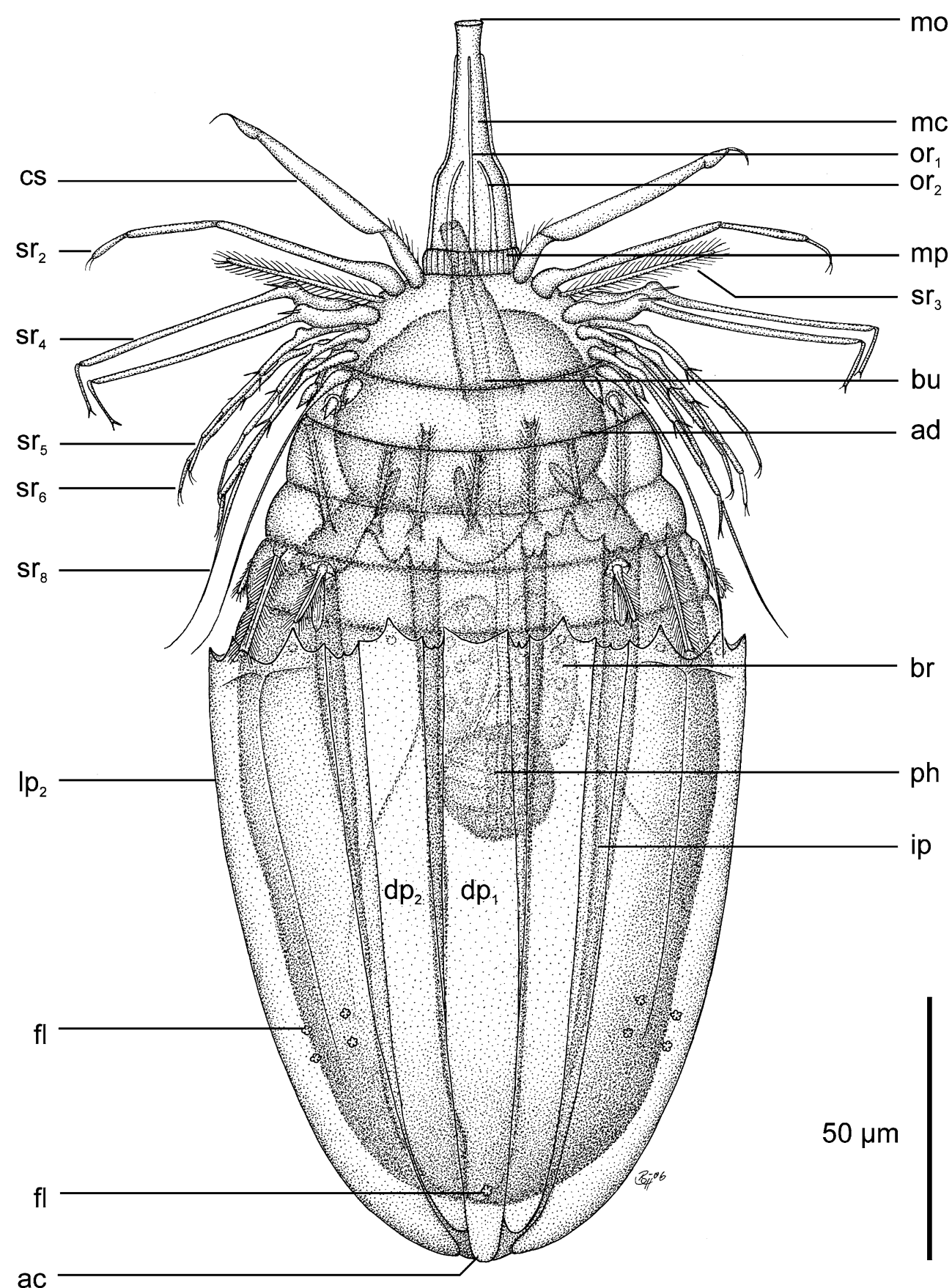

ac

length of the whole scalid and has a knee, which is not so pronounced as the one in the fourth row. Between the first and the second segments there are two stiff hairs, the second and the third segments are short, and the fourth segment is also short with two stiff terminal hairs. The seventh row is absent in the postlarva, though present in the adult and identical to the fifth and sixth row. The eighth row $\left(\mathrm{sr}_{8}\right)$ consists of 30 uniform spinoscalids alternating with 30 "alternating" plates (al). The 30 uniform, long and whip-like scalids $(59 \mu \mathrm{m})$ are without any segmentation. The "alternating" plates are short and rectangular with a stiff hair in the middle. The ninth row $\left(\mathrm{sr}_{9}\right)$ consists of 30 beak-like scalids positioned on round basal plates. The beaklike scalid is rectangular and has one stiff hair on each side.

The neck consists of three rows of trichoscalid basal plates $\left(\mathrm{tp}_{1-3}\right)$ with 15 basal plates in each row. Additionally, there are 15 trichoscalids of which seven are double and eight are single. The first basal plate row $\left(t p_{1}\right)$ is positioned just below the ninth row of the introvert. These basal plates are weakly defined, since the 
Fig. 5 Photos of the holotypic postlarva of Spinoloricus turbatio gen. et sp. nov. with an adult inside. a overview, b mouth cone, $\mathbf{c}$ flosculi, $\mathbf{d}$ buccal tube and pharynx, e single trichoscalid and anterior part of lorica. Arrows indicate the additional spikes, $\mathbf{f}$ double trichoscalid and the edge of lorica. ad Adult, $b u$ buccal tube, $f$ flower-shaped flosculus, $m c$ mouth cone, $m p$ mouth cone pleat, $o r_{1}$ primary oral ridge, $o r_{2}$ secondary oral ridge, $p h$ pharynx, $t r_{a}$ single trichoscalid, $t r_{b 1}$ primary appendage of double trichoscalid, $t r_{b 2}$ secondary appendage of double trichoscalid
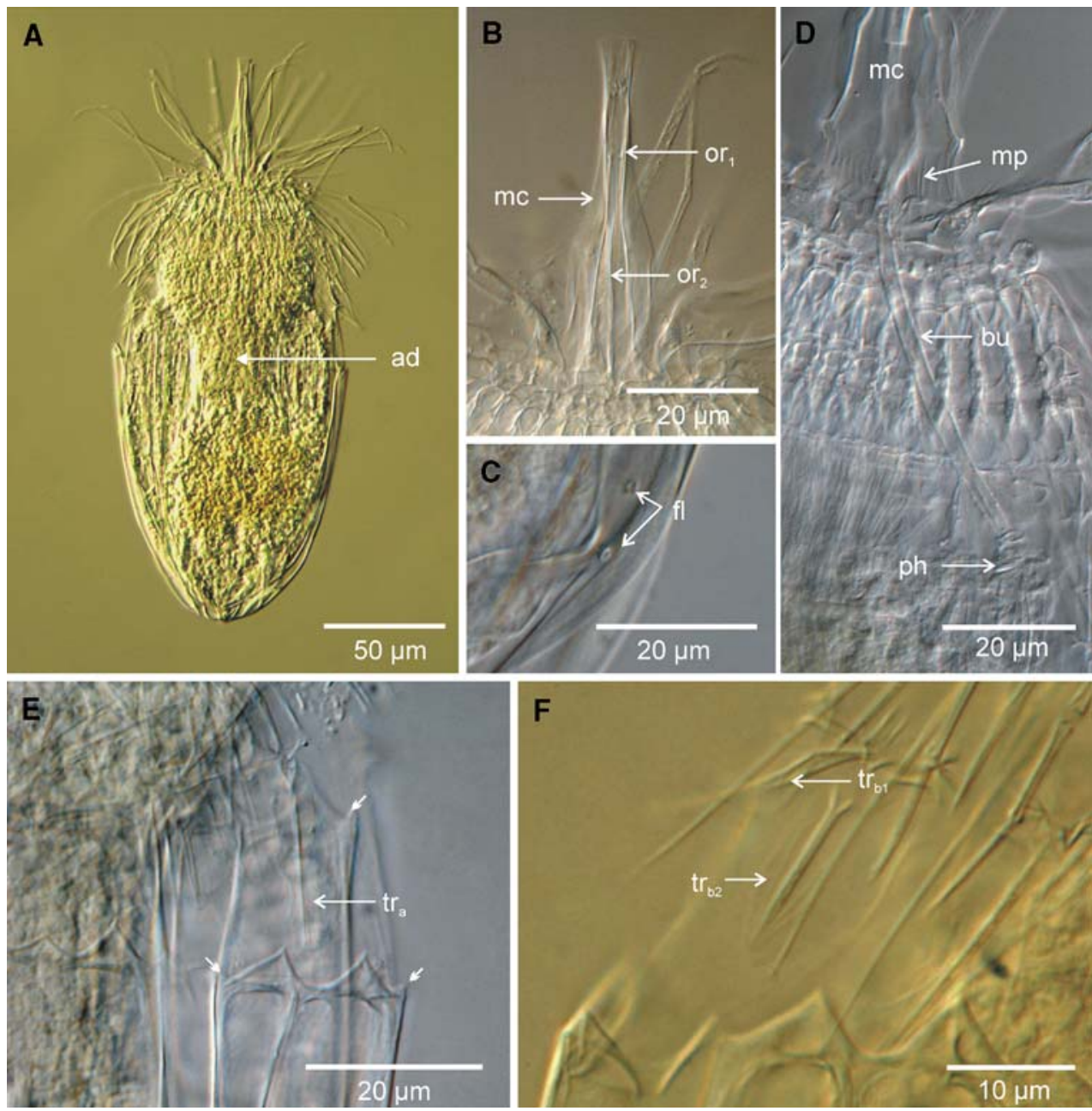

postlarva is in the moulting stage. The first basal plate row has eight half moon-shaped plates and seven thin rectangular plates. These plates are very indistinct and can only be seen with high magnification. Below the first basal plate row there are two large transverse folds and the next two rows of basal plates are found even more posteriorly on the neck. These two rows of basal plates are fused together making it difficult to see the distinction between the plates. In the second basal plate row $\left(\mathrm{tp}_{2}\right)$ there are only seven basal plates, since the other eight basal plates are totally fused with the basal plates below. The seven basal plates are half moon-shaped and connected to the plates are the seven primary appendages of the double trichoscalids $\left(\operatorname{tr}_{\mathrm{b} 1}\right)$. The third basal plate row $\left(\mathrm{tp}_{3}\right)$ has eight rectangular basal plates alternating unevenly with seven triangular basal plates. The eight rectangular basal plates support the eight single trichoscalids $\left(\operatorname{tr}_{\mathrm{a}}\right)$ and the seven triangular basal plates support the seven secondary appendages of the double trichoscalids $\left(\operatorname{tr}_{\mathrm{b} 2}\right)$. The single trichoscalids are $20 \mu \mathrm{m}$ long and have highly serrated margins of numerous fine hairs. The primary appendages of the double trichoscalids are also highly serrated with numerous fine hairs, though shorter $(12 \mu \mathrm{m})$ than the single trichoscalids. The secondary appendages of the double trichoscalids are $11 \mu \mathrm{m}$ long, clavoid and with smooth margins. The secondary appendages have distinct middle ridges. The thorax region is broad $(18 \mu \mathrm{m})$ with no appendages, but with a large transverse fold and the region is not hidden by the spikes of the lorica.

The lorica (lo) consists of eight cuticular plates with square-shaped honeycomb sculpture. The 15 anterior spikes on the lorica plates are quite short $(7 \mu \mathrm{m})$ and in the anterior corners of the plates there are additional spikes (see arrows Figs. 2, 5e). There are intercalary plicae (ip) between the different lorica plates. On the midventral plate (vp, Fig. 2) the midventral spike is shorter than the other two spikes. The two ventrolateral plates $\left(\mathrm{lp}_{1}\right.$, Fig. 2$)$ have two spikes with additional spikes in the corners of each plate. The dorsolateral plates $\left(\mathrm{lp}_{2}\right)$ are broad and with four flower-shaped flosculi (fl) on each plate (Fig. 4). These two plates also have two anterior spikes on 
Fig. 6 Drawing of the paratypic Higgins-larva of Spinoloricus turbatio gen. et sp. nov., ventral view. ag abdominal glandular structure, $c p$ closing plate of thorax, cs clavoscalid, $l a_{1}$ anterolateral seta, $l a_{2}$ anteromedian seta, $l a_{3}$ anteroventral seta, lo lorica, mo mouth opening, $m u$ mucrones, $s e_{2}$ posterolateral seta, $s r_{2-7}$ scalid in 2 nd to 7 th row, $t g$ toe glands, th thorax, to toe, $t u$ tubes

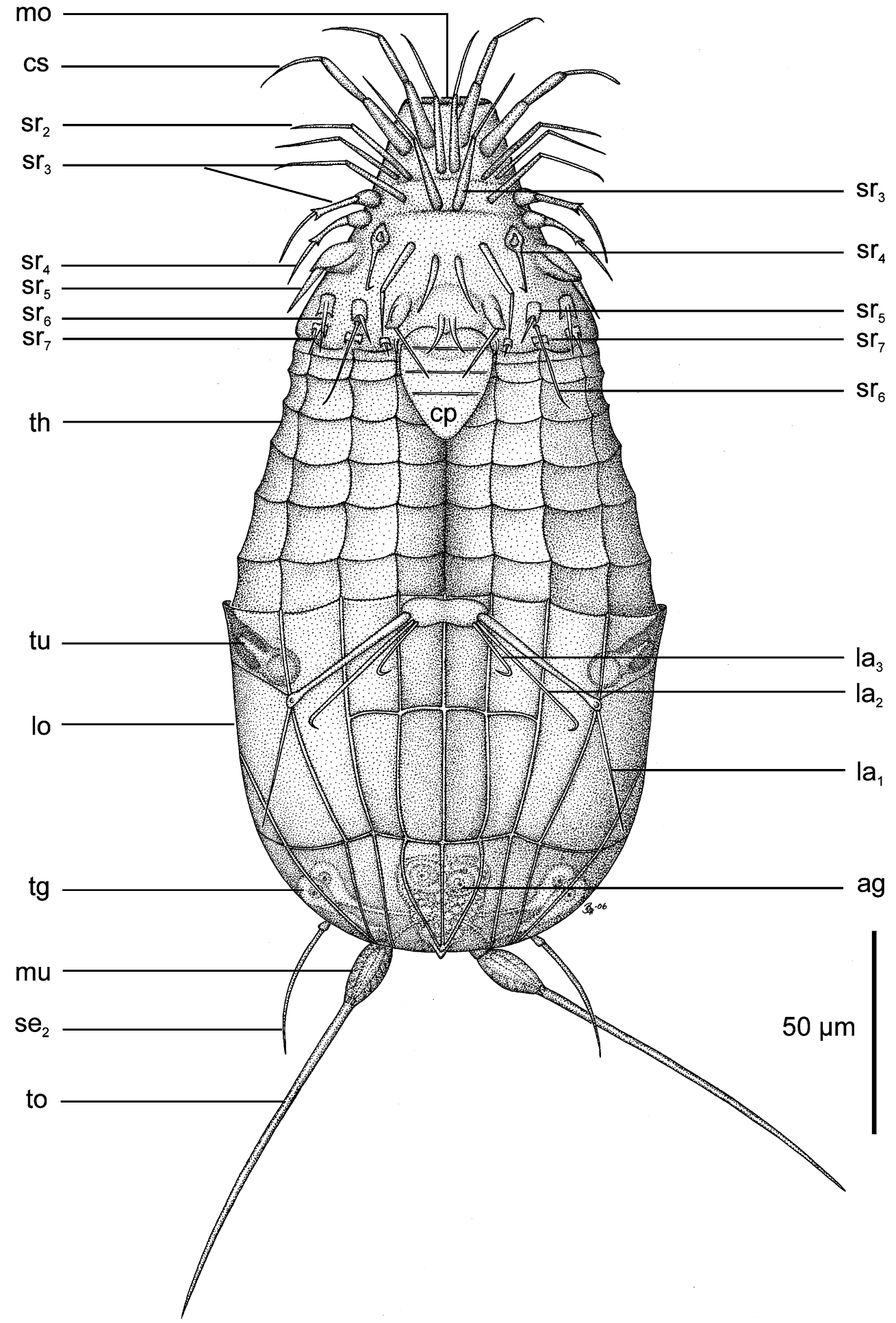

each plate. The posterior part of the lorica is difficult to observe because of the moulting of the animal and therefore the posterior connections between the different dorsal plates $\left(\mathrm{dp}_{1}\right.$ and $\left.\mathrm{dp}_{2}\right)$ are difficult to describe (Fig. 4). However, there is a single flosculus (fl) on the middorsal plate $\left(\mathrm{dp}_{1}\right)$ and the anal cone (ac) is located posteriorly.
Internally, in the holotypic postlarva there is an almost fully developed adult ready to emerge from the postlarva (Figs. 4, 5a). The scalids on the introvert of the internal adult are not drawn on Fig. 4, only the trichoscalids. Internally in the adult, a buccal tube (bu), a brain (br) and a pharyngeal bulb (ph) with a total of 15 placoids inside can be seen. 
Fig. 7 Drawing of the paratypic Higgins-larva of Spinoloricus turbatio gen. et sp. nov., dorsal view. ag Abdominal glandular structure, an anus, $c s$ clavoscalid, $f$ flowershaped flosculus, lo lorica, mo mouth opening, $m u$ mucrones, $s e_{1}$ posterodorsal seta, $s e_{2}$ posterolateral seta, $\mathrm{Se}_{3}$ posteroterminal seta, $s r_{2--7}$ scalid in 2 nd to 7 th row, $t g$ toe glands, th thorax, to toe

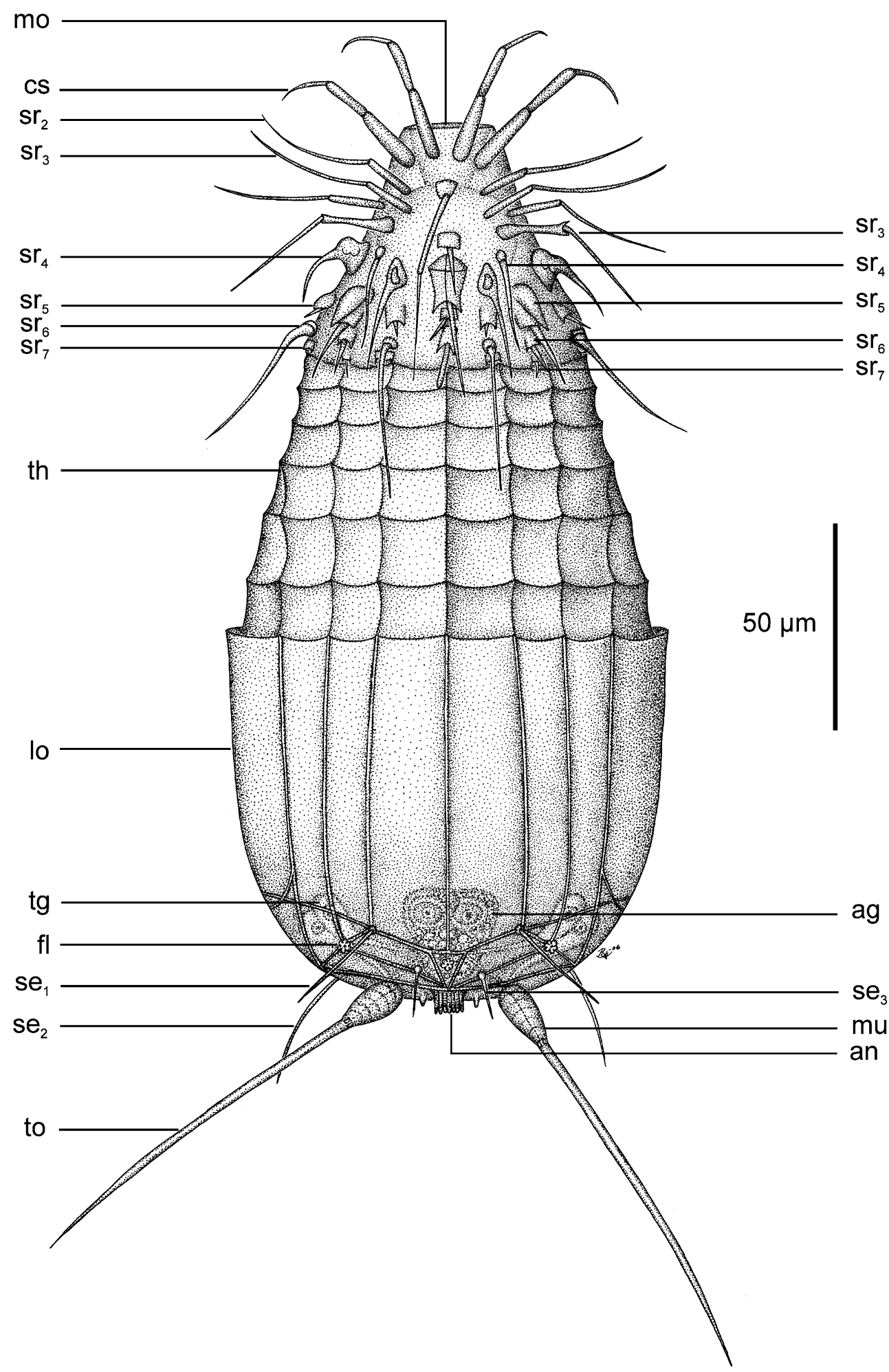

\section{Description of the Higgins-larva}

The paratypic Higgins-larva is $210 \mu \mathrm{m}$ long and $109 \mu \mathrm{m}$ wide (Figs. 6, 7, 8, 9, 10). The mouth cone is retracted into the introvert (Fig. 9), but it would be cone-shaped if fully extended. No external or internal armatures are found.
The introvert has seven rows of scalids with the scalid formula: 8-6-15-15-15-13-13 (see Fig. 8 for more detailed information on the different scalids). The first row (cs) consists of eight three-segmented clavoscalids. All segments are long $(12-16 \mu \mathrm{m})$, smooth and the last segment is slightly hook-shaped. The second row $\left(\mathrm{sr}_{2}\right)$ 

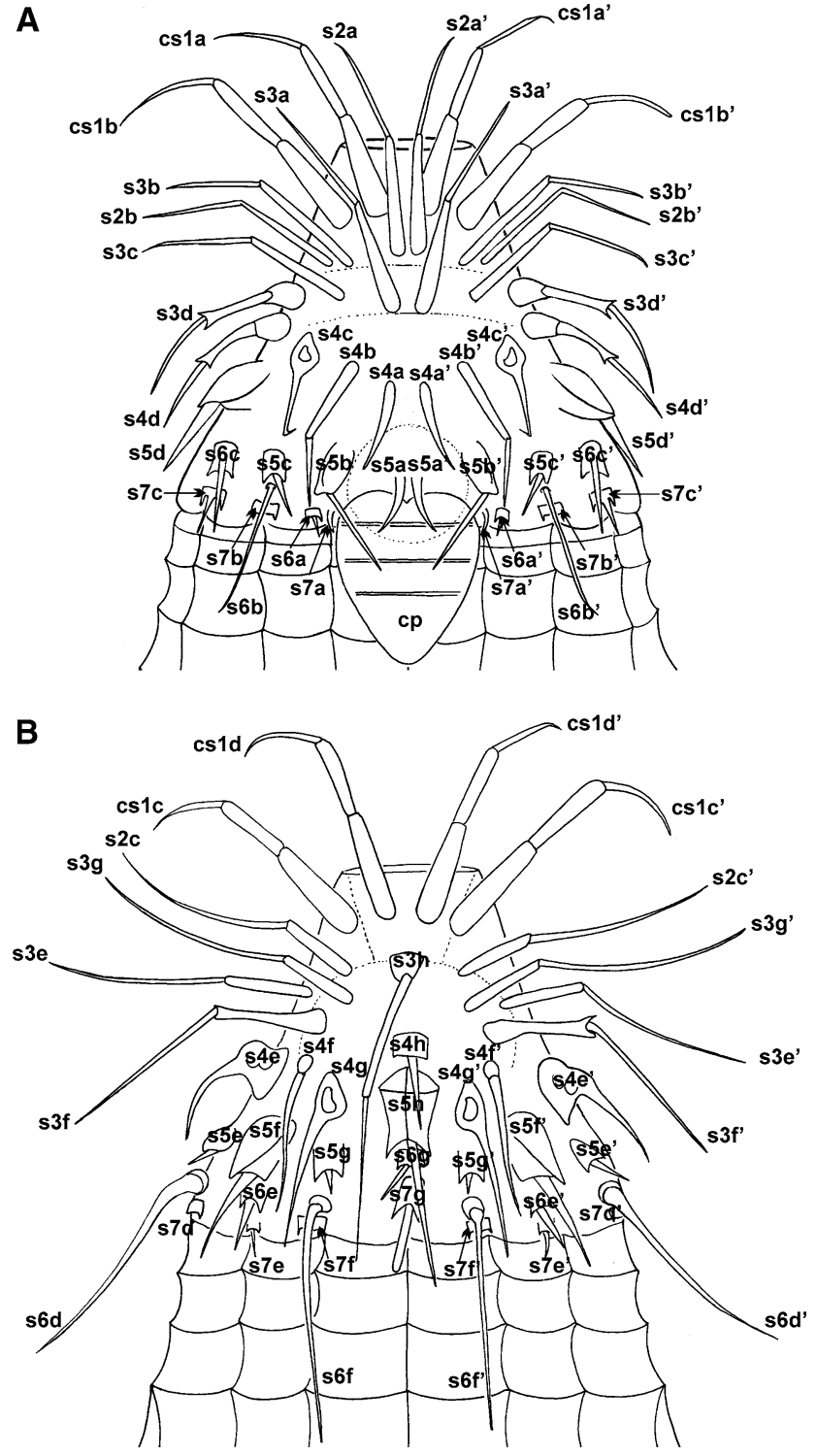

Fig. 8 Drawing of the paratypic Higgins-larva of Spinoloricus turbatio gen. et sp. nov., close-up of introvert with the different scalids a ventral view, b dorsal view. $\operatorname{cs} 1 a-a^{\prime}-c s 1 d-d^{\prime}$ clavoscalids, $s 2 a-a^{\prime}-s 7 g$ the different spinoscalids in the 2 nd to 7 th row

consists of six scalids. All scalids are elongated, spinose and two-segmented. The dorsal pair $\left(\mathrm{s} 2 \mathrm{c}-\mathrm{c}^{\prime}\right)$ has a curved second segment, which curves in an anterior direction. The third row $\left(\mathrm{sr}_{3}\right)$ consists of 15 spinoscalids. The middorsal scalid (s3h) is very long $(49 \mu \mathrm{m})$ and spinose with a rectangular base. The two dorsal pairs $\left(\mathrm{s} 3 \mathrm{e}-\mathrm{e}^{\prime}, \mathrm{s} 3 \mathrm{~g}-\mathrm{g}^{\prime}\right)$ resemble the dorsal pair of the previous row with a curved second segment. The last dorsal pair $\left(\mathrm{s} 3 \mathrm{f}-\mathrm{f}^{\prime}\right)$ is two-segmented with a distinct knee between the two segments. Dorsally, there are three pairs $\left(\mathrm{s} 3 \mathrm{a}-\mathrm{a}^{\prime}, \mathrm{s} 3 \mathrm{~b}-\mathrm{b}^{\prime}, \mathrm{s} 3 \mathrm{c}-\mathrm{c}^{\prime}\right)$ of spinose, elongated, simple and two-segmented scalids. On the ventral side is a ventrolateral pair $\left(\mathrm{s} 3 \mathrm{~d}-\mathrm{d}^{\prime}\right)$ that is three-

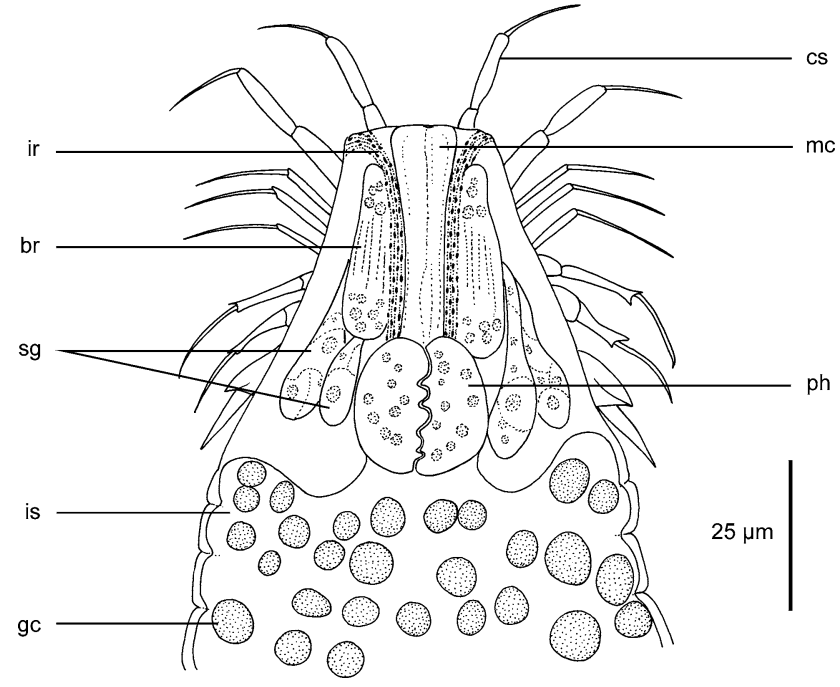

Fig. 9 Drawing of the paratypic Higgins-larva of Spinoloricus turbatio gen. et sp. nov., internal view of introvert. cs clavoscalid, $b r$ brain, $g c$ granular storage cells, ir internal retractor muscles, is intestinal system, $m c$ mouth cone, $p h$ pharynx, $s g$ salivary glands

segmented with a large bulbous base and a pronounced knee with two spines. The fourth row $\left(\mathrm{sr}_{4}\right)$ consists of 15 spinoscalids. The midventral pair $\left(\mathrm{s} 4 \mathrm{a}-\mathrm{a}^{\prime}\right)$ is slightly hook-shaped and curves towards the lateral sides. The next ventral pair (s4b-b') is two-segmented and spinose. The last two ventral pairs $\left(\mathrm{s} 4 \mathrm{c}-\mathrm{c}^{\prime}, \mathrm{s} 4 \mathrm{~d}-\mathrm{d}^{\prime}\right)$ have both a bulbous base, where the first pair $\left(\mathrm{s} 4 \mathrm{c}-\mathrm{c}^{\prime}\right)$ is two-segmented and the last segment ends in a claw. The other pair $\left(\mathrm{s} 4 \mathrm{~d}-\mathrm{d}^{\prime}\right)$ is three-segmented and resembles the other lateral pair of the third row. On the dorsal side the most lateral pair $\left(\mathrm{s} 4 \mathrm{e}-\mathrm{e}^{\prime}\right)$ has a very large base with a short second segment. The scalid resembles the head of a bird in profile. The next pair $\left(s 4 f-f^{\prime}\right)$ is two-segmented and whip-like. The s4g-g' pair is twosegmented with a large base and a spinose last segment. The middorsal scalid (s4h) is short, two-segmented and with a rectangular base. The fifth row $\left(\mathrm{sr}_{5}\right)$ consists of 15 spinoscalids. The midventral pair (s5a$\left.a^{\prime}\right)$ is hook-shaped and shorter than the same pair in the previous row. The next pair $\left(s 5 b-b^{\prime}\right)$ is a large clawshaped scalids without any diagonal ridges. The other two pairs of claw-shaped scalids $\left(\mathrm{s} 5 \mathrm{~d}-\mathrm{d}^{\prime}, \mathrm{s} 5 \mathrm{f}-\mathrm{f}^{\prime}\right)$ are in contrast larger and have very pronounced diagonal ridges and a central ridge. The $\mathrm{s} 5 \mathrm{c}-\mathrm{c}^{\prime}, \mathrm{s} 5 \mathrm{e}-\mathrm{e}^{\prime}$ and $\mathrm{s} 5 \mathrm{~g}-$ $\mathrm{g}^{\prime}$ pairs are two-segmented with a rectangular base and a short distal segment. The middorsal scalid (s5h) of this row is also a claw-shaped scalid, but with a very large shield-shaped base and a long distal segment. The sixth row $\left(\mathrm{sr}_{6}\right)$ consists of 13 spinoscalids. In this row there are three pairs of long, spinose two-segmented scalids $\left(s 6 b-b^{\prime}, s 6 d-d^{\prime}, s 6 f-f^{\prime}\right)$ with a small base alternating with seven short scalids. The ventral pair of the 
Fig. 10 Photos of the paratypic Higgins-larva of Spinoloricus turbatio gen. et sp. nov. a overview, b introvert, $\mathbf{c}$ dorsal view of the posterior part of the lorica, $\mathbf{d}$ internal view of the posterior part of the lorica with the toe glands. $a g$ Abdominal glandular structure, an anus, $f$ flower-shaped flosculus, $g c$ granular storage cells, $m u$ mucrones, $p h$ pharynx, $s e_{1}$ posterodorsal seta, $s e_{2}$ posterolateral seta, $\mathrm{se}_{3}$ posteroterminal seta, $s r_{3-6}$ scalid in 3rd to 6th row, $\operatorname{tg}$ toe glands, to toe
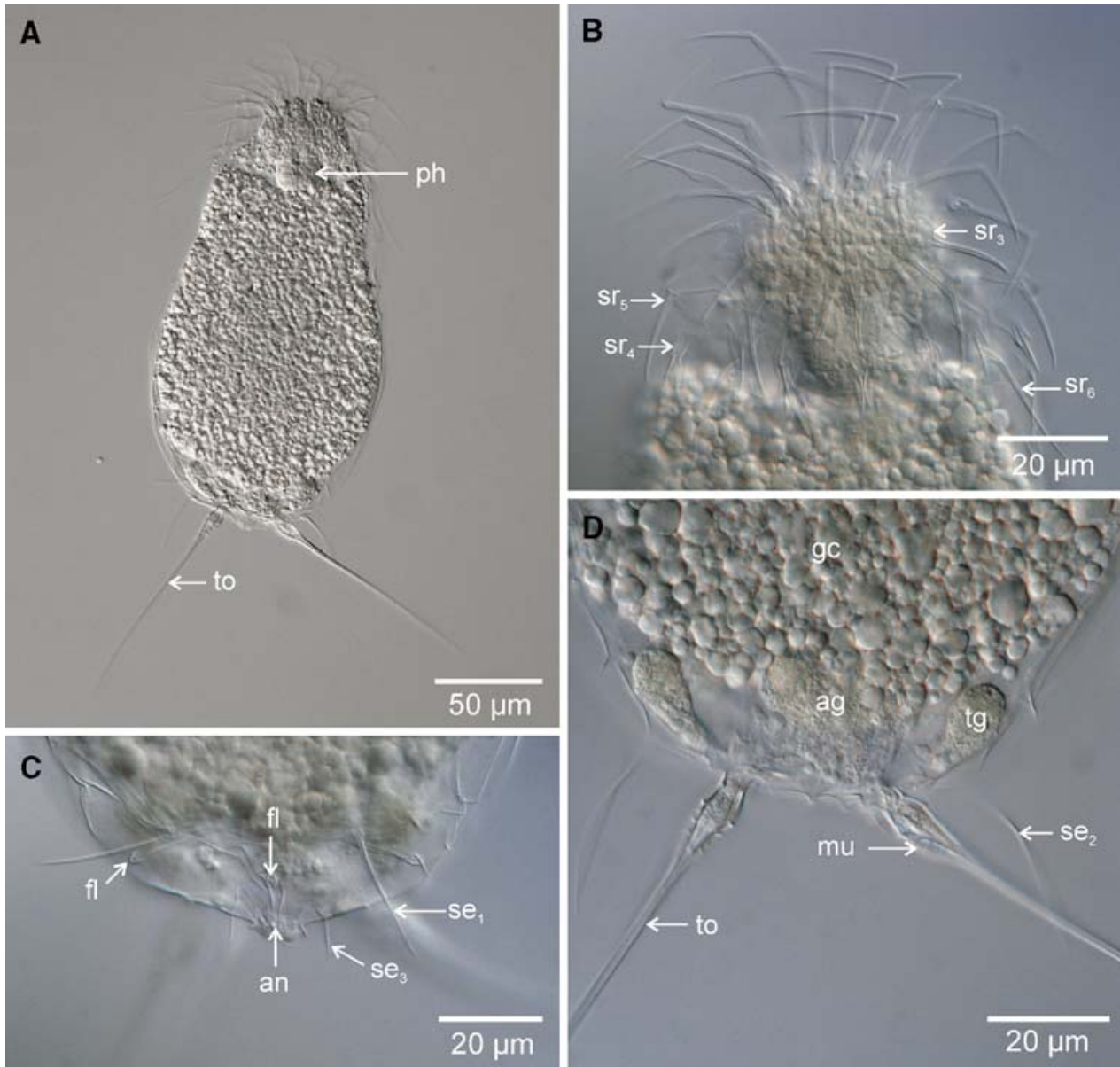

long spinose scalids $\left(s 6 b-b^{\prime}\right)$ is shorter $(14 \mu \mathrm{m})$ than the other two dorsal pairs $(39 \mu \mathrm{m})$. The most ventral pair $\left(\mathrm{s} 6 \mathrm{a}-\mathrm{a}^{\prime}\right)$ of the short scalids is very short $(3 \mu \mathrm{m})$ compared to the other five scalids $(12-15 \mu \mathrm{m})$. The short scalids (s6a-a', s6c- $c^{\prime}$, s6e-e $\left.e^{\prime}\right)$ are two-segmented with a triangular or rectangular base and a short distal spine. The seventh row $\left(\mathrm{sr}_{7}\right)$ consists of 13 spinoscalids, in which six rectangular plates alternate with six short scalids and a clavoid scalid. The three pairs of rectangular plates $\left(\mathrm{s} 7 \mathrm{~b}-\mathrm{b}^{\prime}, \mathrm{s} 7 \mathrm{~d}-\mathrm{d}^{\prime}, \mathrm{s} 7 \mathrm{f}-\mathrm{f}^{\prime}\right)$ have a single small tooth on both sides. The short scalids $\left(\mathrm{s} 7 \mathrm{c}-\mathrm{c}^{\prime}, \mathrm{s} 7 \mathrm{e}-\mathrm{e}^{\prime}\right)$ resemble the smallest of the short scalids $\left(s 6 a-a^{\prime}\right)$ of the previous row except for the $\mathrm{s} 7 \mathrm{a}-\mathrm{a}^{\prime}$ pair, which is only a short tooth. The clavoid scalid (s7g) is two-segmented with a large base and a smooth and flattened spine.

The thorax (th) is accordion-like with five to six transverse and 16 longitudinal folds. A large heartshaped closing plate ( $\mathrm{cp}$ ) is positioned ventrally and is used as a lid for when the introvert is retracted into the abdomen. The closing plate has three distinct transverse ridges.

Ventrally, located on a peanut-shaped plate there are three pairs of ventral locomotory setae. The ante- rolateral setae $\left(\mathrm{la}_{1}\right)$ are very long $(68 \mu \mathrm{m})$ with a pronounced knee. The next setae, the anteromedial setae $\left(\mathrm{la}_{2}\right)$ are long $(38 \mu \mathrm{m})$ with a terminal claw. The last setae, the anteroventral setae $\left(\mathrm{la}_{3}\right)$, are identical to the medial setae though shorter $(17 \mu \mathrm{m})$. Laterally, there is a pair of tubes (tu) connected to two multicellular glands, and the tubes are positioned inside a pocket/ fold in the cuticle of the abdomen (Fig. 6). The tubes are sometimes pushed out of their pockets so that the tubes can be seen from the outside.

The loricated abdomen (lo), as well as the thorax, has an indistinct honeycomb sculpture, which is only visible at very high magnification. The shape of the honeycomb is more rounded in appearance than the typical hexagonal shape. There are 16 longitudinal folds together with a few transversal and diagonal folds on the lorica. Posteriorly, there is a pair of $106 \mu \mathrm{m}$ long toes (to) with very little mucrones $(\mathrm{mu})$. The mucrones are only found on the very basis of the toes and have five transverse ridges. The toes are connected to the abdomen by ball and socket joints. Additionally, there are three pairs of posterior setae and dorsally three flower-shaped flosculi (fl). The first pair of posterior setae $\left(\mathrm{se}_{1}\right)$, the posterodorsal, is found on the dorsal 
side. These setae are $27 \mu \mathrm{m}$ long and thin with a small rounded base. The second pair of setae $\left(\mathrm{se}_{2}\right)$, the posterolateral, are longer that the first $(28 \mu \mathrm{m})$ with a rectangular base. The last pair the posteroterminal setae $\left(\mathrm{se}_{3}\right)$ are quite long $(12 \mu \mathrm{m})$ with a round base. An anus (an) with many wrinkles is found in the posterior end between to small rectangular protrusion (Fig. 7).

Internally, inside the introvert (Fig. 9) the retracted mouth cone $(\mathrm{mc})$ can be seen. Six internal retractor muscles (ir) (only two are shown in Fig. 9) and the brain (br) surrounds the retracted mouth cone. The external retractor muscles are not shown in Fig. 9. The brain consists of three parts: an 8-ganglionated forebrain, a glial midbrain and a 10-ganglionated hindbrain. Posterior and lateral to the brain are two pairs of salivary glands (sg), the pharynx (ph) and the intestinal system (is). The pharynx is large and ovoid without any kind of internal armature. The intestinal system consists of large granular storage cells (gc). Additionally, in the posterior end of the lorica, there are four toe glands (tg) (Figs. 7, 8, 10d). Two of the toe glands (the most posterior ones) are directly connected to the toes and the glands terminate out in the toes. The other two toe glands are connected to a large abdominal glandular structure (ag) of unknown function.

\section{Discussion}

Diagnostic features and comparisons

The new genus and species Spinoloricus turbatio gen. et sp. nov. is included in the family Nanaloricidae because of the following family-specific characters in the postlarvae/adults: (1) postlarva resembling the adult female except for the lack of the seventh row of scalids on the introvert and the lack of the reproductive organs; (2) mouth cone with eight oral ridges and a spiralized telescopical buccal tube; (3) third row with feather-shaped scalids; (4) trichoscalids consisting of eight single and seven double, where the two appendages in the double ones are situated on separate basal plates; and (5) lorica consisting of six to ten cuticularized plates and with four flosculi on each dorsolateral plate. The Higgins-larvae show the following familyspecific characters: (1) mouth cone without internal and external armature; (2) three pairs of ventrolateral setae; (3) three pairs of posterior setae; and (4) toes with different types of leaf-shaped structures called mucrones.

Spinoloricus turbatio gen. et sp. nov. possesses the following genus-specific as well as species-specific characters in the postlarvae/adults: (1) mouth cone basally with a cuticularized reinforcement called a mouth cone pleat; (2) the eighth row consists of 30 whip-like uniform scalids alternating with 30 "alternating" plates; (3) the single trichoscalids are twice the length of the double trichoscalids and the secondary appendage of the double trichoscalid is smooth compared to the serrated primary appendage; (4) eight lorica plates with short spikes and with additionally spikes in each corner in the anterior part of the plate; and (5) intercalary plicae, cuticular folds, between the lorica plates. The genus-specific characters for the Higgins-larvae are: (1) seventh row with rectangular plates with two teeth; (2) thorax and lorica with indistinct honeycomb sculpture; and (3) toes with very small mucrones. These genusspecific characters of the postlarvae/adults and Higgins-larvae of Spinoloricus nov. gen. are also found in two new species of the same genus, one from the Atalanta basin in the Mediterranean Sea and the other from the deep sea in the Gulf of Mexico (unpublished data by senior author).

Concerning the genus-specific characters of the postlarvae and the adults in Spinoloricus nov. gen. four characters are here discussed in detail, namely the mouth cone pleat, the "alternating" plates in the eighth row, the additional spikes on the lorica plates and the intercalary plicae. The presence of a reinforcement resembling a pleat on the mouth cone, the mouth cone pleat (mp, Figs. 2, 5d) has never been described for any other loriciferan species. The mouth cone pleat in Spinoloricus nov. gen. is not identical to the collar-like structures found on the large paedogenetic ghost-larvae of the new order from the GSC (Table 1) and from the Faroe Bank (Heiner 2005) and additionally the Higgins-larvae of Pliciloricus gracilis and P. profundus (Higgins and Kristensen 1986), since their collars are positioned below the introvert and not on the mouth cone. The mouth cone pleat found in the postlarva of Spinoloricus nov. gen. might resemble the ruff found in many adults of the Pliciloricidae (Higgins and Kristensen 1986; Heiner and Kristensen 2005). However, the ruff, with its 15 thick cuticular fibers formed by tanocytes, is used to move the mouth cone out or into the introvert, whereas the pleat in Spinoloricus nov. gen is just an external non-movable structure. The mouth cone can in Spinoloricus nov. gen not be retracted into the introvert, as it can be in species of the Pliciloricidae.

The "alternating" plates in the eighth row of the introvert (Figs. 2, 3) have never been observed before in species of the Nanaloricidae, though several times in species of the Pliciloricidae, e.g., Pliciloricus leocaudatus (see Heiner and Kristensen 2005), Rugiloricus cauliculus (see Higgins and Kristensen 1986) and in a new 
species of Rugiloricus from the Faroe Bank. "Alternating" plates can be found both in the eighth row as in Spinoloricus nov. gen. and P. leocaudatus or in the 9th row as in $R$. cauliculus and the new species from the Faroe Bank. Since "alternating" plates are found in several species of the Loricifera, it might be a plesiomorphic character, which then has been lost several times. The additionally spikes (see arrows on Figs. 2, $5 \mathrm{e}$ ) on the lorica plates is a unique structure for this new genus and is not observed in any other described species of the Nanaloricidae (see Kristensen 1983; Todaro and Kristensen 1998; Gad 2004; Heiner 2004; Kristensen and Gad 2004). The postlarvae/adults of Spinoloricus nov. gen. have intercalary plicae between the lorica plates, which resembles the plicae found in all species of Pliciloricidae. The presence of intercalary plicae in Spinoloricus nov. gen. shows the linkage between the two families Nanaloricidae and Pliciloricidae. However, a cladistic analysis is needed to say whether the presence of plica, normal or intercalary, is a plesiomorphic or an apomorphic character.

Generally the postlarvae/adults of Spinoloricus nov. gen. resemble mostly the genus Nanaloricus compared with the other two genera, Armorloricus and Phoeniciloricus, in the family Nanaloricidae. This is especially concerning the shape of the mouth cone with a short mouth tube and eight oral ridges of two different lengths (Fig. 2) compared with the long mouth tubes and eight oral ridges of equal length in the other two genera (see Kristensen 1983; Gad 2004; Heiner 2004; Kristensen and Gad 2004). There is a total of 15 primary lorica spikes in the genera Spinoloricus nov. gen., Nanaloricus and Armorloricus, whereas in Phoeniciloricus there are only 13 spikes. Additionally, both the postlarvae and the adults of Spinoloricus nov. gen. have eight lorica plates, whereas there are only six lorica plates in Nanaloricus and Armorloricus and ten plates in Phoeniciloricus.

The Higgins-larva of Spinoloricus nov. gen. has generally very simple spinoscalids resembling the Higginslarvae of both Nanaloricus and Armorloricus. However, there are some distinct differences. There are six spinoscalids in the second row of Spinoloricus nov. gen. The number of spinoscalids in the second row varies considerably among species of the Nanaloricidae, e.g., N. mysticus has seven (Kristensen 1983), A. kristenseni has zero (Heiner 2004), whereas Phoeniciloricus simplidigitatus has ten spinoscalids (Gad 2004); therefore this character is probably very variable for all nanaloricids. Another difference in the Higgins-larva is the shape of the six plates found in the seventh row. This is a genus-specific character. In Spinoloricus nov. gen. the six plates are rectangular with one tooth on each side.
In Nanaloricus the plates consist of a double teeth-like structure with many minute teeth (Kristensen 1983) and in Armorloricus the plates are triangular spiny plates with seven teeth on each plate (Kristensen and Gad 2004). The Higgins-larva of Spinoloricus nov. gen. has a very indistinct rounded honeycomb sculpture on the surface of the body cuticle compared with nearly all described nanaloricid species, which have very distinct hexagonal-shaped honeycomb (Kristensen 1983; Heiner 2004; Kristensen and Gad 2004). The only nanaloricid species, which also has an indistinct honeycomb sculpture is P. simplidigitatus (see Gad 2004), though in this species the shape of the honeycomb is hexagonal and not rounded as in Spinoloricus nov. gen. The size of the mucrones on the toes is very small in the Higgins-larvae of Spinoloricus nov. gen. compared with the large mucrones found in Nanaloricus and Armorloricus, though larger than the slightly elevated lateral bars found on the basis of the toes in P. simplidigitatus (Gad 2004).

\section{Life cycle of Spinoloricus turbatio gen. et sp. nov}

The life cycle of Spinoloricus turbatio gen. et sp. nov. is presumed to be identical to that of all described nanaloricids. All described species of the Nanaloricidae have a typical sexual reproductive cycle with an egg, Higgins-larva, postlarva and adults as described by Kristensen (1991) and Kristensen and Brooke (2002). However, this new species reveals a very interesting new detail of the life cycle of the Nanaloricidae, namely the presence of a postlarva with an adult inside. Postlarvae with adults inside have never been found before, although several species of Nanaloricidae have been intensively researched in the last 15 years in Roscoff, France. The moult from a postlarva to an adult is generally thought to be extremely brief for shallow-water nanaloricids or it would have been expected that at least a single moulting postlarva would have been found in Roscoff. It has therefore, for the first time, definitely been proven that the nanaloricid postlarvae moult into adults in the same way as do members of the family Pliciloricidae, and not just presumed, as it was before (Kristensen 1991).

More than half the specimens found near the GSC are in a moulting stage with a new stage inside. Hence, the different life stages are possibly postponed in the deep sea and the previous outer life stage might act as a dormant shelter for the next stage. This is, e.g., seen in Titaniloricus inexpectatovus where several different life history stages such as a ghost-larva, Higgins-larvae, postlarvae and adults, are found within one very large Higgins-larva ( Gad 2005a). This is also the case in the 
new order (nov. gen. 2, Table 1) from the GSC and the Faroe Bank (Heiner 2005). The reasons for this possible postponement and shelter of the different stages are at the moment purely speculative. Gad (2005a) postulates that one of the key reasons for deep-sea species to produce potentially dormant stages with postponed development is the extremely poor food conditions in the deep sea. However, the nutritional conditions in the deep sea probably vary considerably from area to area and do influence at least the abundance of meiofaunal and macrofaunal species in the Angola Basin (Kröcke and Türkay 2003; Rose et al. 2005). Therefore nothing definite can be said about the exact reasons.

Acknowledgments We greatly appreciate superb support by Captain Hartmut Andresen and his crew of R/V Sonne in collecting sediment during the expedition SO 158. Special thanks are also due to the chief scientist Dr. Reinhard Werner as well as to the shipboard scientific party for consistent help and advice during the cruise. Our thanks go to Prof. Kaj Hoernle and Dr Folkmar Hauff (IfM-GEOMAR, Kiel) for letting B.N. participate in the expedition. We are grateful for stimulating and scholastic discussions with Prof. Reinhardt M. Kristensen (Zoological Museum, Copenhagen) during the preparation of the manuscript. We gratefully acknowledge technical support by Denise Czech, Jana Hoffmann, Kristine Kämpf, Ingeborg Kilias, Karin Meschter and Antje Schwiering (Museum für Naturkunde) as well as scientific advice by Dr José Vargas (Centro de Investigación en Ciencias del Mar y Limnología, Costa Rica). The Governments of Columbia, Costa Rica, Ecuador, and Panama are appreciated for their permission to work in their territorial waters. Loan of a large-volume centrifuge during SO 158 by Thermo Electron Corporation is gratefully acknowledged. B.N. wishes to express his sincere gratitude to the Bundesministerium für Bildung und Forschung (BMBF) for funding the expedition SO 158 and to the Deutsche Forschungsgemeinschaft (DFG) for funding sampling during SO 158 (NE 446/3-1). I.H. thanks Birgitte Rubæk, Zoological Museum of Copenhagen, for all her help in making the line-art drawings of this new genus and species.

\section{References}

Ax P, Schmidt P (1973) Interstitielle Fauna von Galapagos. I. Einführung. Mikrofauna Meeresbod 20:1-38

Bates JW (1997) The slide-sealing compound "glyceel". J Nematol 29:565-566

Bauer-Nebelsick M (1996) Antygomonas oreas sp.n. a new deep sea kinorhynch from the Pacific Ocean (Kinorhyncha: Cyclorhagida). Ann Nat Mus Wien 98B:5-22

Cruz E de la, Vargas JA (1987) Abundancia y distribución vertical de la meiofauna en la playa fangosa de Punta Morales, Golfo de Nicoya, Costa Rica. Rev Biol Trop 35:363-367

Gad G (2004) A new genus of Nanaloricidae (Loricifera) from deep-sea sediments of volcanic origin in the Kilinailau Trench north of Papua New Guinea. Helgol Mar Res $58: 40-53$

Gad G (2005a) Giant Higgins-larvae with paedogenetic reproduction from the deep sea of the Angola Basin-evidence for a new life cycle and for abyssal gigantism in Loricifera? Org Divers Evol 5:59-75
Gad G (2005b) A parthenogenetic, simplified adult in the life cycle of Pliciloricus pedicularis sp. n. (Loricifera) from the deep sea of the Angola Basin (Atlantic). Org Divers Evol 5:77-103

Gad G (2005c) Successive reduction of the last instar larva of Loricifera, as evidenced by two new species of Pliciloricus from the Great Meteor Seamount (Atlantic Ocean). Zool Anz 243:239-271

Guzmán HM, Obando VL, Cortés J (1987) Meiofauna associated with a Pacific coral reef in Costa Rica. Coral Reefs 6:107-112

Heiner I (2004) Armorloricus kristenseni (Nanaloricidae, Loricifera), a new species from the Faroe Bank (North Atlantic). Helgol Mar Res 58:192-205

Heiner I (2005) Preliminary account of the Loriciferan Fauna of the Faroe Bank (NE Atlantic) BIOFAR proceedings 2005. Ann Soc Scient Færoensis Suppl 41:213-219

Heiner I, Kristensen RM (2005) Two new species of the genus Pliciloricus (Loricifera, Pliciloricidae) from the Faroe Bank, North Atlantic. Zool Anz 243:121-138

Higgins RP, Kristensen RM (1986) New Loricifera from Southeastern United States coastal waters. Smithson Contr Zool 438:1-70

Kristensen RM (1983) Loricifera, a new phylum with Aschelminthes characters from the Meiobenthos. Z zool Syst Evolutforsch 21:163-180

Kristensen RM (1991) New higher taxa-presented by their discoverers. Loricifera-a general biological and phylogenetic overview. Verh Dtsch Zool Ges 84:231-246

Kristensen RM, Brooke S (2002) Phylum Loricifera, Chap. 8. In: Young CM, Sewell MA, Rice ME (eds) Atlas of marine invertebrate larvae. Academic, London, pp 179-187

Kristensen RM, Shirayama Y (1988) Pliciloricus hadalis (Pliciloricidae), a new loriciferan species collected from the Izu-Ogasawara Trench, Western Pacific. Zool Sci (Japan) 5:875-881

Kristensen RM, Gad G (2004) Armorloricus a new genus of Loricifera (Nanaloricidae) from Trezen ar Skoden (Roscoff, France). Cah Biol Mar 45:121-156

Kristensen RM, Heiner I, Jørgensen A (2003) The mysterious "Ghostlarva" from the deep sea is a loriciferan larva. First International DIVA Workshop, Wilhelmshaven, pp 30-31 (abstract)

Kristensen RM, Heiner I, Higgins RP (2007) A new loriciferan from the Atlantic coast of Florida with an emended diagnosis and life cycle of Nanaloricidae (Loricifera). Invertebrate Biol (in press)

Kröcke I, Türkay M (2003) Structure and function of benthic communities in the deep Angola Basin in relation to food availability. Mar Ecol Progr Ser 260:43-53

Mielke W (1995) Species of the taxon Schizopera (Copepoda) from the Pacific coast of Costa Rica. Microf Mar 10:89-116

Mielke W (2003) Meiobenthic copepods of Galápagos: species composition, distribution, colonization, speciation. Bull Mar Sci 73:557-568

Neuhaus B (2004) Description of Campyloderes cf. vanhoeffeni (Kinorhyncha, Cyclorhagida) from the Central American East Pacific deep sea with a review of the genus. Meiof Mar 13:3-20

Neuhaus B, Blasche T (2006) Fissuroderes, a new genus of Kinorhyncha (Cyclorhagida) from the deep sea and continental shelf of New Zealand and from the continental shelf of Costa Rica. Zool Anz 246:19-52

Rose A, Seyfried S, Willen E, George KH, Veit-Köhler G, Bröhldick K, Drewes J, Moura G, Arbizu PM, Schminke HK (2005) A method for comparing within-core alpha diversity values from repeated multicorer samplings, shown for abyssal Harpacticoida (Crustacea: Copepoda) from the Angola Basin. Org Divers Evol 5:3-17 
Todaro MA, Kristensen RM (1998) A new species and first report of the genus Nanaloricus (Loricifera, Nanaloricida, Nanaloricidae) from the Mediterranean Sea. Ital J Zool 65:219-226

Vargas JA (1988) A survey of the meiofauna of an Eastern tropical Pacific intertidal mud flat. Rev Biol Trop 36:541-544
Werner R (2002) Cruise report SO 158 MEGAPRINT. GEOMAR Report 104: 1-53 + VIII appendices

Westheide W (1991) The meiofauna of the Galápagos. A review. In: James MJ (ed) Galápagos marine invertebrates. Taxonomy, biogeography, and evolution in Darwin's islands. Plenum Press, New York, pp 37-73 